\title{
Plants from the Brazilian Cerrado with antimycobacterial effect
}

\author{
Plantas do Cerrado com efeito antimicobacteriano \\ Franciano Dias Pereira Cardoso' \\ Marcio Galdino dos Santos" \\ Sergio de Albuquerque \\ Zumira Aparecida Carneiro ${ }^{\mathrm{V}}$ \\ Aparecido Osdimir Bertolin $\vee$
}

\section{Abstract}

Tuberculosis constitutes a serious public health problem because it has multi-resistant forms that require treatment that is both difficult and extensive. There is a need to develop new antimycobacterial compounds, and plants represent a source of therapeutic resources. This study analyzed antimycobacterial action in eight extracts from plants found in the Brazilian Cerrado. The results showed significant inhibitory concentrations in relation to Mycobacterium tuberculosis, especially from the extracts of Apuleia molaris and Ouratea spectabilis, both of which presented reduced cytotoxic effects. Fractionation revealed a hexane fraction of $A$. molaris with significant and promising activity regarding future in vivo assays.

Keywords: Cerrado; Public health; Tuberculosis

\section{Resumo}

A tuberculose representa um sério problema de saúde pública diante as formas multirresistentes, tratamentos extensivos e dificuldades à adesão. Há necessidade em desenvolver novos compostos antimicobacterianos, sendo as plantas uma fonte de recursos terapêuticos. Este estudo analisou ação antimicobacteriana em oito extratos de plantas presentes no Cerrado. Os resultados demonstraram expressivas concentrações inibitórias para Mycobacterium tuberculosis com destaque para Apuleia molaris e Ouratea spectabilis, ambos apresentaram reduzidos efeitos citotóxicos, cujo fracionamento relevou uma fração hexânica de A. molaris com atividade significativa e promissora para futuros ensaios in vivo.

Palavras-chave: Cerrado; Saúde Pública; Tuberculose

\footnotetext{
I Mestre em Ciências Ambientais e Especialista em Gestão Pública pela Universidade Federal do Tocantins. e-mail: francianocardoso@hotmail.com II Doutor em Química pela Universidade Federal de São Carlos. Professor associado da Fundação Universidade Federal do Tocantins. 


\section{Introduction}

Tuberculosis (TB) is mainly caused by the Mycobacterium tuberculosis bacillus (PANDIT et al., 2015) and it represents a serious public health problem worldwide (BOTTGER, 2011). There were 10.4 million new $\neg$ cases and 1.4 million deaths due to TB reported in 2015, which reflects an infectious disease with high mortality rates (WHO, 2016).

The high rates of incidence and prevalence of TB in developing countries have an impact on morbidity and mortality, particularly because the incidence of the human immunodeficiency virus (HIV) is also high (ALFFENAAR et al., 2017).

Increased numbers of cases of MDR-TB (multidrug-resistant tuberculosis) (PANDIT et al., 2015) and XDR-TB (extensively drug-resistant tuberculosis) (PARIDA et al., 2015) have made it difficult to control this disease because the latter do not adequately correspond to treatment (SINGH et al., 2015), as well as presenting higher toxicity and treatment costs (TIBERI et al., 2017b).

There has been scant development of new drugs to treat TB. This represents a challenge and new research is required in relation to factors such as new mechanisms of action (SINGH and MIZRAHI, 2017), reduced treatment period (SANDGREN et al., 2009), increased effectiveness regarding resistant strains (TIBERI et al., 2017a), and reduced adverse effects of treatment (KUETE, 2010).

Natural products, especially plants, are capable of providing innovative structures for the formulation of new drugs (SANTHOSH and SURIYANARAYANAN, 2013). They are important sources of bioprospecting for antimycobacterial compounds (PAULI et al., 2005), and trials involving plant extracts are increasingly more frequent (FIDELIS et al., 2014; MOLINA-SALINAS et al., 2010).

The Brazilian Cerrado is a promising biome because it contains specimens with pharmacological potential (NOVAES et al., 2013), expressive phytophysiological heterogeneity, and floristic richness (SANO et al., 2010). The Cerrado contains more than 12,000 plant species, approximately $30 \%$ of which are endemic to the region (FORZZA et al., 2010).

The Cerrado is considered to be the planet's richest tropical savannah in terms of biodiversity (SANO et al., 2010); it occupies an area of approximately 1,783 million square kilometers, which represents $22 \%$ of the Brazilian territory (JEPSON, 2005). However, increasing levels of agribusiness have had negative impacts on this biodiversity and resulted in changes in the water cycle (SPERA et al., 2016).

The Cerrado is considered to be a hotspot in terms of biodiversity. It is a region with an exceptional concentration of endemic species which results from a great loss of natural areas (MITTERMEIER et al., 2004, MYERS et al., 2000). Its preservation is a priority, although in Brazil only $3 \%$ of this biome is legally protected by preservation areas (FRANÇOSO et al., 2015).

Due to this urgent scenario, and the estimated pharmacological potential within the Cerrado, this study analyzed specimens found in the Cerrado. There are currently few scientific studies regarding the antimycobacterial activity of such specimens.

\section{Materials and Methods}

\subsection{Botanical Material}

All the botanical material was collected from the Cerrado biome in the Brazilian state of Tocantins. The specimens were identified in the herbarium of the Federal University of Tocantins (UFT), Porto Nacional campus.

\subsection{Preparation of extracts}

The samples were dried at room temperature, ground in a knife mill, and packed in amber flasks to percolate in $70 \%(\mathrm{v} / \mathrm{v})$ ethanol for 72 hours at $25^{\circ} \mathrm{C}$, protected from light.

The solutions were filtered and their solvents were removed using a rotary evaporator to concentrate the crude extracts. The extracts were lyophilized and stored at $-20^{\circ} \mathrm{C}$.

\subsection{Phytochemical screening}

The processes of phytochemical identification, fractionation and the production of the extracts were conducted at the UFT Phytochemical Laboratory. For the phytochemical analysis, a qualitative, preliminary, prospection methodology was followed, based on the detection of some important constituents of the secondary metabolite groups (SIMÕES et al., 2007).

\subsection{Fractionation}

The extracts with potential activity against Mycobacterium tuberculosis were fractionated. An aliquot of $5.0 \mathrm{~g}$ of each extract was solubilized in $100 \mathrm{~mL}$ of methanolic solution $\left(\mathrm{MetOH}: \mathrm{H}_{2} \mathrm{O}\right)$ in a $4: 1$ ratio and then partitioned into a separatory funnel using solvent of increasing polarity: $\mathrm{n}$-hexane $(5 \times 30 \mathrm{~mL})$ and dichloromethane $(5 \times 30$ $\mathrm{mL})$. The solvents were removed using a rotary evaporator and the extracts were lyophilized and packaged at $-20^{\circ} \mathrm{C}$.

\subsection{Microbiological assays}

The analysis of antimycobacterial activity was performed at the Central Laboratory of Public Health of Tocantins (LACEN-TO) using the MABA (microplate alamar blue assay) method described by Franzblau et al. (1998). The assays used the Mycobacterium tuberculosis, $\mathrm{H}_{37} \mathrm{Rv}$ standard strain, ATCC (American Type Culture Collection) 27294, which was provided by the Professor Hélio Fraga Reference Center/Fiocruz, Rio de Janeiro, Brazil.

The mycobacterial suspension (1:25), in $7 \mathrm{H} 9$ medium (4.7g of Middlebrook 7H9 broth base - Difco) with 10\% ADC (albumin, dextrose and catalase), was prepared from the inoculum (H37Rv) on the No. 1 McFarland standard scale $\left(3.2 \times 10^{6} \mathrm{CFU} / \mathrm{mL}\right)$. Rifampicin -RIF- (Sigma-Aldrich) 
was chosen as the standard antibiotic.

The dried extracts were dissolved in Type I water containing $1 \%$ DMSO (dimethylsulfoxide) and subjected to sterile filtration $(0.22 \mu \mathrm{m})$. These were adjusted to an initial concentration of $250 \mu \mathrm{g} / \mathrm{mL}$, followed by two-fold, serial dilutions to a final concentration of $0.49 \mu \mathrm{g} / \mathrm{mL}$. For the RIF, an initial concentration of $32 \mu \mathrm{g} / \mathrm{mL}$ and final concentration of $0.0625 \mu \mathrm{g} / \mathrm{mL}$ were used.

The microbiological assays were run in triplicate using sterile, 96-well microplates, which were sealed and incubated for seven days at $37{ }^{\circ} \mathrm{C}$. After this period, 30 $\mu \mathrm{L}$ of $0.01 \%(\mathrm{w} / \mathrm{v})$ resazurin was added to all the wells and re-incubated for 24 hours before the readings were taken.

The minimum inhibitory concentration (MIC) was determined as the lowest concentration of extract that prevented a change of color to pink. Extracts with MIC $<100 \mu \mathrm{g} / \mathrm{mL}$ were considered to be promising regarding antimycobacterial activity according to the classification criteria adopted by Kuete (2010).

\subsection{Cytotoxicity Study}

The extracts that were identified as having significant antimycobacterial activity (MIC $<100 \mu \mathrm{g} / \mathrm{mL}$ ) were evaluated for cytotoxicity. For these assays, the following two cell lines were used: LLC-MK ${ }_{2}$ (ATTC CCL-7) and Vero (ATCC CCL-81). Mosmann's methodology (MOSMANN, 1983) was followed, using MTT (3-(4,5-dimethylthiazol-2-yl) 2,5-diphenyltetrazolium bromide). The experiments were performed at the Laboratory of Parasitology of the Department of Clinical, Toxicological and Bromatological Analysis at the University of São Paulo (USP) in the city of Ribeirão Preto.

The cells were cultured in Dulbecco's modified eagle medium (DMEM) supplemented with $10 \%$ fetal bovine serum (FBS), streptomycin $(100 \mu \mathrm{g} / \mathrm{mL})$, penicillin $(100 \mathrm{IU} / \mathrm{mL})$ and amphotericin B $(25 \mu \mathrm{g} / \mathrm{mL})$. The cells were then incubated in a $5 \%, \mathrm{CO}_{2}$ oven, under a humid atmosphere of $37^{\circ} \mathrm{C}$ until
$80 \%$ confluence; they were subsequently diluted in phosphate-buffered saline (PBS) for $1 \times 10^{6}$ cells $/ \mathrm{mL}$. Cell viability was assessed using the Trypan blue exclusion method.

In sterile, 96 -well microplates, $200 \mu \mathrm{L}$ of cell suspension ( 106 cells $/ \mathrm{mL}$ ) was pipetted into all orifices; after 48 hours incubation half of this volume was discarded. The extracts then underwent serial, two-fold dilutions (500$3.9 \mu \mathrm{g} / \mathrm{mL}$ ): $100 \mu \mathrm{L}$ of each concentration was pipetted into the wells using cellular carpet and then re-incubated for 24 hours. Subsequently, $50 \mu \mathrm{L}$ of MTT $(2.5 \mathrm{mg} / \mathrm{mL})$ was added to all the wells, followed by a wait of three hours. Then, $50 \mu \mathrm{L}$ of DMSO was added to dissolve the formazan blue crystals the absorbance was read at 570 nm using a Stat Fax 2100 microplate spectrophotometer (Awareness Technology, Palm City, FL, USA). In the case of the untreated cells, the extracts were replaced with water and represented $100 \%$ viability, while Triton X-100 solution was used as a positive control.

\subsection{Statistical Analysis}

The experiments were conducted in triplicate on alternate days. $\mathrm{The}_{\mathrm{IC}}$ (inhibitory concentration) value corresponds to $50 \%$ inhibition of cell growth, which was determined by a dose-response curve prepared using GraphPad Prism, version 5.0, Windows software. The analysis between the different groups was performed using the Student's t-test method and the differences were considered significant when $\mathrm{p} \leq 0.05$.

\section{Results}

Eight hydroalcoholic extracts of plants from the Cerrado biome in Tocantins, Brazil were selected and evaluated for antimycobacterial activity, as shown in Table 1.

The extracts of Apuleia molaris and Ouratea spectabilis

Table 1 - Relationship of Cerrado plants used in the microbiological assays against M. tuberculosis $\mathrm{H}_{37} \mathrm{Rv}$ (ATCC 27294) and their respective inhibitory concentrations.

\begin{tabular}{lcccc}
\hline Botanical species & Vernacular & $\begin{array}{c}\text { Herbal } \\
\text { registration }\end{array}$ & Part extracted $^{\mathrm{b}}$ & MIC $(\mathrm{\mu g} / \mathrm{mL})^{\text {a }}$ \\
\hline Plathymenia reticulata Benth & Vinhático & 10.072 & Bark & $(-)^{\mathrm{d}}$ \\
Ouratea spectabilis (Mart. Ex Engl.) & Cabeça de negro & 9.547 & Bark & 62.5 \\
Galactia glauscescens Kunth & Três folhas & 10.070 & Branches and leaves & $(-)^{\mathrm{d}}$ \\
Apuleia molaris Spruce ex Benth & Grapia & 9.614 & Branches and leaves & 62.5 \\
Dipteryx alata Vogel & Baru & 9.687 & Bark & 125.0 \\
Brosimum gaudichaudii Trécul. & Inharé & 10.068 & Bark & 125.0 \\
Tabebuia caraíba (Mart.) Bureau & Paratudo & 9.680 & Bark & 125.0 \\
Terminalia fagifolia Mart. & Camaçari & 10.842 & Bark & $(-)^{\mathrm{d}}$ \\
\hline
\end{tabular}

$\mathrm{a}$ - specimens were identified in the herbarium of the UFT; $\mathrm{b}-70 \%$ alcoholic extract $(\mathrm{v} / \mathrm{v})$; $\mathrm{c}-$ minimum inhibitory concentration; $\mathrm{d}$ - absence of antimycobacterial effect at a concentration of $250 \mu \mathrm{g} / \mathrm{mL}$. Note: RIF presented MIC $=0.5 \mu \mathrm{g} / \mathrm{mL}$. 
showed the most significant inhibitory concentrations (MIC $<100 \mu \mathrm{g} / \mathrm{mL}$ ), with promising antimycobacterial potential according to the classification criteria adopted by Kuete (2010). The other extracts produced moderate activity $(100<$ MIC $\leq 625 \mu \mathrm{g} / \mathrm{mL})$ against the $\mathrm{M}$. tuberculosis strain. Only the extracts with significant MICs were selected for the processes of phytochemical identification, cytotoxicity and partitioning, i.e. those lower than $100 \mu \mathrm{g} / \mathrm{mL}$.

The phytochemical assays for A. molaris and O. spectabilis showed positive indications in both extracts of the qualitative presence of saponins, tannins, phenols, flavonoids, steroids and triterpenoids.

In relation to the cytotoxicity experiments involving Vero cells, the graph (FIGURE 1) of the log scale showed a growth curve of cell death as the concentration of the extracts increased.

Figure 1 - Cytotoxicity $\left(\mathrm{IC}_{50}\right)$ for the crude extracts of O. spectabilis and A. molaris in relation to Vero cells $\left(1.0 \times 10^{6}\right.$ cells $\left./ \mathrm{mL}\right)$.

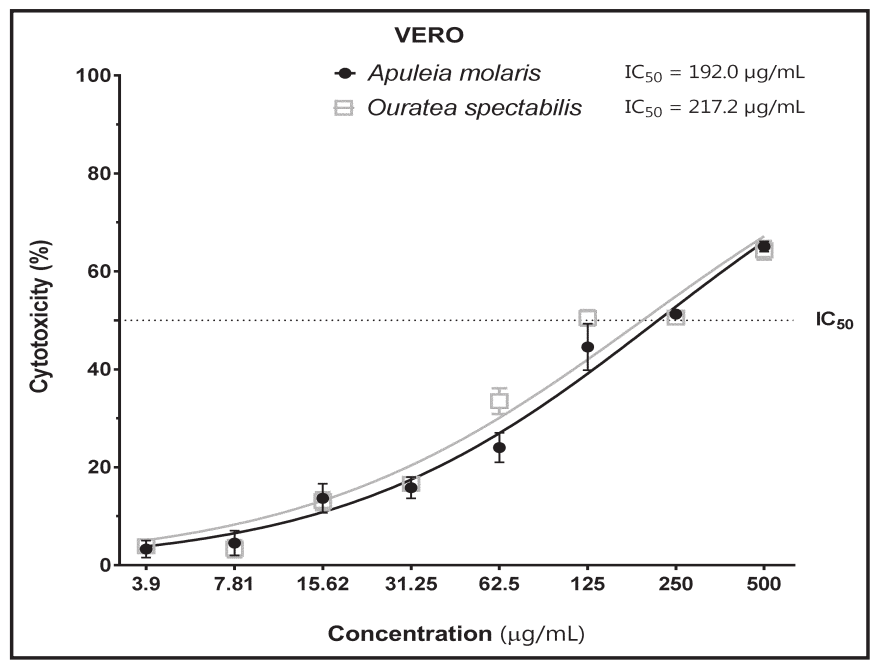

The $\mathrm{IC}_{50}$ values were $192.0 \mu \mathrm{g} / \mathrm{mL}$ for A. molaris and $217.2 \mu \mathrm{g} / \mathrm{mL}$ for O. spectabilis (FIGURE 1). There was no statistical difference between the paired data $(\mathrm{t}=1.23, \mathrm{p}$ $=0.26$ ) and their curves showed a similar performance; thus, both extracts demonstrated mild levels of cytotoxicity in relation to Vero cells.

The A. molaris extract presented a mild cytotoxic effect $\left(\mathrm{IC}_{50}=95.2 \mu \mathrm{g} / \mathrm{mL}\right)$ and $O$. spectabilis presented moderate cytotoxicity $\left(\mathrm{IC}_{50}=49.8 \mu \mathrm{g} / \mathrm{mL}\right)$ in relation to the LLC-MK ${ }_{2}$ cell line (FIGURE 2). Although there were distances between some points of the curve, in the case of the statistical analysis of the t-student test there was no significant difference between the assays $(\mathrm{t}=2.23$; $\mathrm{p}$ $=0.06$ ).

In the partitioning step, three different fractions were obtained for each sample, which were evaluated again for their antimycobacterial effect (TABLE 2). The fractions (HEX, $\mathrm{DCM}, \mathrm{MetOH}$ ) of O. spectabilis did not provide as good results as the crude extract, demonstrating a possible synergistic effect between the substances present in its composition.
The hexanic fraction of A. moralis showed the best results regarding the ability to inhibit the $\mathrm{H}_{37} \mathrm{Rv}$ strain. It is likely that this fraction isolated apolar compounds of the steroid and terpenoid type, demonstrating efficacy against M. tuberculosis.

Figure 2 - Cytotoxicity (IC ${ }_{50}$ ) for the crude extracts of $O$. spectabilis and A. molaris in relation to LLC-MK ${ }_{2}$ cells $\left(1.0 \times 10^{6} \mathrm{cel} / \mathrm{mL}\right)$.

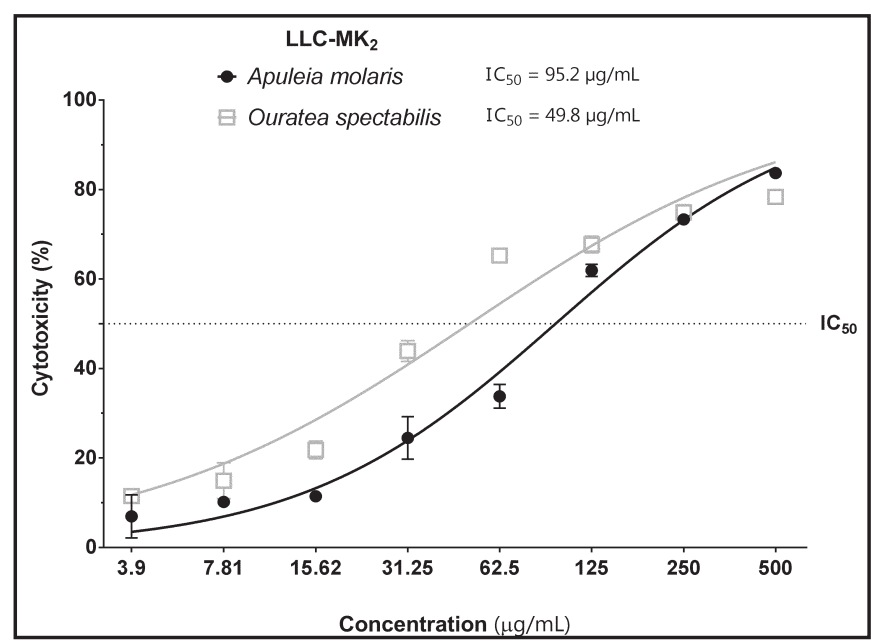

Table 2 - Minimal inhibitory concentrations (MIC) of different fractions obtained from the crude extracts of Ouratea spectabilis and Apuleia molaris against the M. tuberculosis strain.

\begin{tabular}{lccc}
\hline Extract & Fraction $^{*}$ & Yield $(\%)$ & MIC $(\mu \mathrm{g} / \mathrm{mL})$ \\
\hline \multirow{3}{*}{ O. spectabilis } & HEX & 10.3 & 250.0 \\
& DCM & 14.5 & 250.0 \\
& MetOH & 22.7 & 125.0 \\
A. molaris & HEX & 16.2 & 31.25 \\
& DCM & 22.8 & 250.0 \\
& MetOH & 30.4 & 250.0 \\
\hline
\end{tabular}

\section{Discussion}

The Fabaceae family is widely distributed in the Cerrado biome (NOVAES et al., 2013) and its representativity was also reflected in the percentage of species collected for this study; $50 \%$ of the samples belong to this family.

The significant antimycobacterial performance of the crude extracts of $A$. molaris and $O$. spectabilis are considered to be relevant ( $\mathrm{MIC} \leq 64 \mu \mathrm{g} / \mathrm{mL}$ ) for pharmacology (CANTRELL et al., 2001). This activity may be due to the presence of tannins, triterpenoids (NAYYAR and JAIN, 2005), flavonoids (MOLINA-SALINAS et al., 2010) and saponins (WINK, 2008), as these are structural classes of metabolites known for their broad spectrum of antimicrobial activity (KUETE, 2010; SANTHOSH and SURIYANARAYANAN, 2013).

The presence of different functional groups in plant extracts allows a variety of mechanisms of action to occur, which reduces bacterial resistance (SINGH et al., 2015). 
The cell membrane is the main target and the majority of mutations are associated with its permeability (PARIDA et al., 2015).

The methanolic fraction of O. spectabilis did not out-perform the results of its crude extract; however, it was the fraction with the best performance. This sample had high polarity and it is very likely to have contained isolated compounds of the flavonoid type. Extracts may contain substances that facilitate the adsorption of polar compounds (WINK, 2008), which would explain the performance of this fraction.

The genus Ouratea, which is present in the Ochnacea family, is characterized as a source of flavonoids and biflavonoids (D'ARC FELICIO et al., 2001). Extracts of the Ouratea species contain biflavonoids that perform important biological activities, with antitumoral (FIDELIS et al., 2014), antiviral (BRANDÃO et al., 2011) and antimicrobial (GANGOUÉ-PIÉBOJI et al., 2006) effects. Extracts of the Ouratea species have demonstrated moderate effects regarding the inhibition of different gram positive, cocci species, especially for Staphylococcus aureus, as well as Candida albicans yeasts.

Previous studies (MECINA et al., 2014; SIMONI et al., 2002; VALADARES et al., 2003) have identified the presence of several types of flavonoids in relation to O. spectabilis, particularly biflavonoids (6,6' '-bigenkwanin; 7-7' '-dimetoxi-agasthisflavona), which reflects a probable association between the antimycobacterial effect for this metabolic group in the methanolic fraction in the present study.

Regarding the evaluation of cytotoxicity, Simoni et al. (2002) and Brandrão et al. (2011) reported that extracts from O. spectabilis leaves had low cytotoxicity. This corroborates with the results of the present study regarding the alcoholic extract of the bark, which was found to have a mild cytotoxic effect.

The hexane, apolar fraction of A. molaris showed a more significant effect in the present study: it was able to penetrate the mycobacterial cell wall, inhibit its growth and cause cell death. Mycobacteria have a hydrophobic cell wall that is rich in lipids (mycolic acids), which are generally susceptible to apolar compounds (NAYYAR and JAIN, 2005; PAULI et al., 2005), and this might explain the good performance of this fraction.

There are few studies regarding the A. molaris species (synonym: A. leiocarpa), most of which are associated with morphological characterization (SOUZA REIS et al., 2016). Some of the existing studies have described antimalarial (MUÑOZ et al., 2000), antibiofilm (SILVA et al., 2015), anti-inflammatory and analgesic (RUPPELT et al., 1991) biological effects, whose properties are correlated with the presence of tannins, flavonoids (WOLLENWEBER and H. DIETZ, 1981), triterpenes and $\beta$-amyrin (MUÑOZ et al., 2000).

Experiments conducted by Silva et al. (2015) in relation to A. leiocarpa fruit (synonym: A. molaris) demonstrated antibiofilm potential against Staphylococcus epidermidis, as well as a low toxicity in relation to Vero cells. This reinforces the promising character of this specimen and highlights the need for further studies to provide better chemical and biological characterization.

\section{Conclusion}

The extracts of Ouratea spectabilis and Apuleia molaris showed chemical variation of secondary metabolites, which changed from polar (flavonoids) to apolar (steroids and triterpenes), suggesting different physiological actions in the face of mycobacterial attack.

The results of this study were expressive, especially when confirming that Apuleia molaris has potential antimycobacterial action and possesses low cytotoxic effect. Such characteristics suggest that it may be used as a future alternative in the treatment of tuberculosis.

\section{References}

ALFFENAAR JWC; AKKERMAN OW; ANTHONY RM; TIBERI S; HEYSELL S; GROBUSCH MP; et al. Individualizing management of extensively drug-resistant tuberculosis: diagnostics, treatment, and biomarkers. Expert Rev. Anti. Infect. Ther. Taylor \& Francis; 2017;15(1):11-21. doi: 10.1080/14787210.2017.1247692

BOTTGER EC. The ins and outs of Mycobacterium tuberculosis drug susceptibility testing. Clin Microbiol Infect. 2011;17(8):1128-34. doi: 10.1111/j.1469-0691.2011.03551.x

BRANDÃO GC; KROON EG; SANTOS JR; STEHMANN JR; LOMBARDI JL; OLIVEIRA AB. Antiviral activity of plants occurring in the State of Minas Gerais (Brazil): Part III. J. Chem. Pharm. Res. 2011;3(4):223-36.

CANTRELL C; FRANZBLAU S; FISCHER N. Antimycobacterial Plant Terpenoids. Planta Med. 2001;67(08):685-94. doi: 10.1055/s-2001-18365

D'ARC FELICIO J; ROSSI MH; PARK HR; GONÇALEZ E; BRAGGIO MM; DAVID JM; et al. Biflavonoids from Ouratea multiflora. Fitoterapia. 2001;72(4):453-5.

FIDELIS QC; RIBEIRO TAN; ARAÚJO MF; DE CARVALHO MG. Ouratea genus: Chemical and pharmacological aspects. Brazilian J. Pharmacogn. 2014;24(1):1-19.

FORZZA RC; LEITMAN PM; COSTA A; CARVALHO JR AA; PEIXOTO AL; WALTER BMT; et al. Catálago de plantas e fungos do Brasil. Instituto de Pesquisas Jardim Botânico do Rio de Janeiro, editor. J. Chem. Inf. Model. Rio de Janeiro; 2010.

FRANÇOSO RD; BRANDÃO R; NOGUEIRA CC; SALMONA YB; MACHADO RB; COLLI GR. Habitat loss and the effectiveness of protected areas in the Cerrado Biodiversity Hotspot. Nat. e Conserv. 2015;13(1):35-40.

FRANZBLAU SG; WITZIG RS; MCLAUGHLIN JC; TORRES P; MADICO G; HERNANDEZ A; et al. Rapid, lowtechnology MIC determination with clinical Mycobacterium tuberculosis isolates by using the microplate Alamar Blue assay. J. Clin. Microbiol. 1998;36(2):362-6. 
GANGOUÉ-PIÉBOJI J; PEGNYEMB DE; NIYITEGEKA D; NSANGOU A; EZE N; MINYEM C; et al. The in-vitro antimicrobial activities of some medicinal plants from Cameroon. Ann. Trop. Med. Parasitol. 2006;100(3):237-43. doi: $10.1179 / 136485906$ X86365

JEPSON W. A disappearing biome? Reconsidering land-cover change in the Brazilian savanna. Geogr. J. 2005;171(2):99-111.

KUETE V. Potential of Cameroonian plants and derived products against microbial infections: A review. Planta Med. 2010;76(14):1479-91.

MECINA GF; SANTOS VHM; DOKKEDAL AL; SALDANHA LL; SILVA LP; SILVA RMG. Phytotoxicity of extracts and fractions of Ouratea spectabilis (Mart. ex Engl.) Engl. (Ochnaceae). South African J. Bot. South African Association of Botanists; 2014;95:174-80. doi: 10.1016/j.sajb.2014.10.002

MITTERMEIER RA; VAN DIJK PP; RHODIN AGJ; NASH SD. Hotspots Revisited: Earth's Biologically Richest and Most Endangered Ecoregions. Chelonian Conserv. Biol. 2004;14(1):200. doi: 10.2744/ccab-1401-2-10.1

MOLINA-SALINAS GM; BÓRQUEZ J; ARDILES A; SAID-FERNÁNDEZ S; LOYOLA LA; YAM-PUC $\mathrm{A}$; et al. Bioactive metabolites from the Andean flora. Antituberculosis activity of natural and semisynthetic azorellane and mulinane diterpenoids. Phytochem. Rev. Elsevier B.V.; 2010;9(2):271-8. doi: 10.1007/s11101-010-9162-4

MOSMANN T. Rapid Colorimetric assay for cellular growth and survival: application to proliferation and cytotoxicity assay. J. Immunol. Methods. 1983;65(12):55-63.

MUÑOZ V; SAUVAIN M; BOURDY G; CALLAPA J; BERGERON S; ROJAS I; et al. A search for natural bioactive compounds in Bolivia through a multidisciplinary approach. J. Ethnopharmacol. 2000;69(2):127-37. doi: 10.1016/S0378-8741(99)00148-8

MYERS N; MITTERMEIER RA; MITTERMEIER CG; DA FONSECA GAB; Kent J. Biodiversity hotspots for conservation priorities. Nature. 2000;403(6772):853-8. doi: $10.1038 / 35002501$

NAYYAR A; JAIN R. Recent Advances in New Structural Classes of Anti-Tuberculosis Agents. Curr. Med. Chem. 2005;12(16):1873-86. doi: 10.2174/0929867054546654

NOVAES P; MOLINILLO JMG; VARELA RM; MACÍAS FA. Ecological phytochemistry of Cerrado (Brazilian savanna) plants. Phytochem. Rev. 2013;12(4):839-55.
PANDIT R; SINGH PK; KUMAR V. Natural Remedies against Multi-Drug Resistant Mycobacterium tuberculosis. J. Tuberc. Res. 2015;03(04):171-83. doi: 10.4236/jtr.2015.34024

PARIDA SK; AXELSSON-ROBERTSON R; RAO M V.; SINGH N; MASTER I; LUTCKII A; et al. Totally drugresistant tuberculosis and adjunct therapies. J. Intern. Med. 2015;277(4):388-405.

PAULI GF; CASE RJ; INUI T; WANG Y; CHO S; FISCHER $\mathrm{NH}$; et al. New perspectives on natural products in $\mathrm{TB}$ drug research. Life Sci. 2005;78(5):485-94.

RUPPELT BM; PEREIRA EF; GONÇALVES LC; PEREIRA NA. Pharmacological screening of plants recommended by folk medicine as anti-snake venom--I. Analgesic and anti-inflammatory activities. Mem. Inst. Oswaldo Cruz. 1991. p. 203-5.

SANDGREN A; STRONG M; MUTHUKRISHNAN P; WEINER BK; CHURCH GM; MURRAY MB. Tuberculosis Drug Resistance Mutation Database. PLoS Med. Public Library of Science; 2009;6(2):e1000002. doi: 10.1371/ journal.pmed.1000002

SANO EE; ROSA R; BRITO JLS; FERREIRA LG; SANO EE; ROSA R; et al. Land cover mapping of the tropical savanna region in Brazil. Env. Monit Assess. 2010;166:11324. doi: 10.1007/s10661-009-0988-4

SANTHOSH R; SURIYANARAYANAN B. Plants: A Source for New Antimycobacterial Drugs. Planta Med. 2013;80(01):9-21. doi: 10.1055/s-0033-1350978

SILVA LN; TRENTIN DDS; ZIMMER KR; TRETER J; BRANDELLI CLC; FRASSON AP; et al. Anti-infective effects of Brazilian Caatinga plants against pathogenic bacterial biofilm formation. Pharm. Biol. 2015;53(3):464-8.

SIMÕES CMO; SCHENKEL EP; GOSMANN G; MELLO JCP; MENTZ LA; PETROVICK PR. Farmacognosia: da planta ao medicamento. 6th ed. Porto Alegre/Florianópolis: UFRGS, UFSC; 2007.

SIMONI IC; FELICIO JD; GONÇALEZ E; ROSSI MH. Comunicação Spectabilis (Ochnaceae ) Em Células De Córnea De Coelho Sirc. 2002;95-7.

SINGH B; JAIN M; SINGH S V.; DHAMA K; ASERI GK; JAIN N; et al. Plants as future source of antimycobacterial molecules and armour for fighting drug resistance. Asian J. Anim. Vet. Adv. 2015;10(9):443-60.

SINGH V; MIZRAHI V. Identification and validation of novel drug targets in Mycobacterium tuberculosis. Drug Discov. Today. Elsevier Ltd; 2017;22(3):503-9. doi: 10.1016/j.drudis.2016.09.010 
SOUZA REIS AR; DE FREITAS AD; MARTINS LEAO NV; DOS SANTOS FILHO BG. Morphological aspects of fruits, seeds, and seedlings, and anatomy of seedlings of apuleia molaris spruce ex benth. J. Seed Sci. 2016;38(2):118-28.

SPERA SA; GALFORD GL; COE MT; MACEDO MN; MUSTARD JF. Land-use change affects water recycling in Brazil's last agricultural frontier. Glob. Chang. Biol. 2016;22(10):3405-13.

TIBERI S; BUCHANAN R; CAMINERO JA; CENTIS R; ARBEX MA; SALAZAR M; et al. The challenge of the new tuberculosis drugs. Press. Medicale. Elsevier Masson SAS; 2017a;46(2):e41-51. doi: 10.1016/j.lpm.2017.01.016

TIBERI S; CARVALHO ACC; SULIS G; VAGHELA D; RENDON A; MELLO FC d. Q; et al. The cursed duet today: Tuberculosis and HIV-coinfection. Press. Medicale. Elsevier Masson SAS; 2017b;46(2):e23-39. doi: 10.1016/j. lpm.2017.01.017

VALADARES YM; OLIVEIRA AB DE; CÔRTES SF; LOMBARDI JA; BRAGA FC. Atividade vasodilatadora in vitro de espécies de Ouratea (Ochnaceae) e de frações de Ouratea Semiserrata (Mart.) Engl. Rev. Bras. Ciências Farm. 2003;39(1). doi: 10.1590/S1516-93322003000100009

WHO. Global Tuberculosis Report 2016. Cdc 2016. 2016;(Global TB Report 2016):214.

WINK M. Evolutionary advantage and molecular modes of action of multi-component mixtures used in phytomedicine. Curr. Drug Metab. 2008;9(10):996-1009.

WOLLENWEBER E; H. DIETZ V. Occurrence and distribution of free flavonoid aglycones in plants. Phytochemistry. 1981;20(5):869-932. 